\title{
PERANCANGAN APLIKASI TOKO ONLINE "XO-LICIOUS" BERBASIS MOBILE WEB PADA SISTEM OPERASI ANDROID
}

\author{
Alifvia Arvi N. ${ }^{1)}$, Kodrat Iman Satoto ${ }^{2)}$, Rinta Kridalukmana ${ }^{2)}$ \\ Program Studi Sistem Komputer, Fakultas Teknik, Universitas Diponegoro, \\ Jln. Prof. Sudharto, Tembalang, Semarang, Indonesia \\ email :arvee_ys@yahoo.co.id
}

\begin{abstract}
ABSTRAK
XO-Licious merupakan sebuah toko online yang bergerak dalam bidang penjualan original CD, official maupun unofficial goods para penyanyi di Asia. Sasaran penjualan dari toko online ini adalah kalangan muda. Agar tidak kalah bersaing dengan banyaknya toko online yang sekarang ada, maka XOLicious membutuhkan suatu terobosan yang dapat mempermudah pembeli untuk melakukan transaksi maupun hanya untuk mendapatkan update terbaru.

Mobile commerce atau seringkali disebut dengan m-commerce adalah pengembangan sistem perdagangan elektronik (e-commerce) dengan menggunakan peralatan portabel/mobile seperti telepon genggam, Smart Phone, PDA, atau Notebook. Aplikasi mobile commerce yang dibangun adalah aplikasi mobile yang dapat berjalan pada sistem operasi android. Karena saat ini android telah menguasai pasar smartphone dan merupakan sistem operasi open source yang mudah untuk dikembangkan. Framework yang digunakan dalam pembuatan m-commerce ini adalah jQuery Mobile dan PhoneGap. Framework framework tersebut tersebut dipilih karena memiliki banyak fitur yang menarik seperti, tampilan jQuery mobile dapat menyesuaikan layar dari perangkat bergerak. Sedangkan PhoneGap merupakan sebuah framework opensource yang digunakan untuk membuat aplikasi cross-platform mobile hanya dengan menggunakan bahasa pemrograman HTML, JavaScript dan CSS

Mobile commerce yang berbasis mobile web akan sangat cocok untuk XO-Liciou. Aplikasi mobile commerce ini dapat mempermudah pelanggan/pembeli untuk memesan barang dari XO-Licious dimanapun dan kapanpun melalui smartphone atau tablet yang telah menjadi gaya hidup remaja saat ini.
\end{abstract}

\section{PENDAHULUAN}

\subsection{Latar Belakang}

Perkembangan teknologi informasi membuat banyak sistem - sistem yang bersifat aplikatif dan real time dibangun sehingga memudahkan setiap orang untuk mengakses informasi terkini dimana pun dan kapan pun. Layanan internet telah dimanfaatkan para pengguna sebagai media untuk melakukan pertukaran data bahkan dimanfaatkan sebagai sarana bisnis mobile commerce atau disebut dengan m-commerce merupakan pengembangan sistem perdagangan elektronik (e-commerce) dengan menggunakan peralatan portabel seperti telepon genggam, Smart Phone, PDA, atau Notebook. Teknologi ini sangat menguntungkan baik bagi pembeli dan penjual. Selain menghemat waktu dan tenaga bagi pembeli, teknologi ini juga terbukti meningkatkan pendapatan perusahaan. Karena pembeli hanya perlu mengaksesnya dari telepon genggam atau mobile device yang selalu pembeli bawa.

Penelitian kali ini dilakukan pada sebuah toko online yang menawarkan $\mathrm{CD}$ asli penyanyi dan band yang ada di Asia. Dikarenakan sasaran dari toko online ini adalah kalangan muda, maka $m$-commerce ini dapat menjadi terobosan baru yang akan sangat dibutuhkan bagi XO-Licious. Sehingga dapat mempermudah pelanggan/pembeli untuk memesan barang dari XO-Licious dimanapun dan kapanpun melalui smartphone maupun tablet yang telah menjadi gaya hidup remaja saat ini.

\subsection{Tujuan}

Tujuan dari tugas akhir ini adalah adalah merancang dan membuat aplikasi untuk $\mathrm{m}_{\text {- }}$ commerce pada sistem operasi Android dengan tampilan yang menarik dan sesuai dengan fungsi serta tujuannya. 


\subsection{Pembatasan Masalah}

Adapun pembatasan masalah pada makalah ini adalah sebagai berikut :

1. Aplikasi ini hanya dapat berjalan pada perangkat bergerak yang menggunakan sistem operasi Android.

2. Lingkup kerja sistem adalah mengolah data produk, data pembeli dan data pemesanana pada "XO-Licious".

3. Sistem ini merupakan versi mobile dari e-commerce yang sudah ada.

\section{DASAR TEORI}

\subsection{Mobile commerce}

Mobile commerce (m-commerce) adalah proses bisnis dalam melakukan transaksi pembelian, penjualan atau pertukaran barang dan jasa serta informasi dengan menggunakan jaringan telekomunikasi mobile. m-commerce dinilai lebih efisien dan fleksibel karena sekarang ini mobilitas masyarakat sangat tinggi. Sehingga hal ini membuat m-commerce memiliki beberapa kelebihan daripada e-commerce antara lain adalah :

1. Perangkat bergerak lebih mudah dibawa dan lebih mudah dipakai untuk mengakses setiap update dimanapun.

2. Perangkat bergerak cenderung lebih murah sehingga dapat terjangkau oleh masyarakat secara lebih luas

3. Lebih mudah digunakan karena $m$ commerce atau mobile-web telah disesuaikan tampilannya untuk versi mobile, ini akan mempercepat transfer data.

\subsection{Flowchart}

Bagan alir (flowchart) merupakan bagan yang menggambarkan urutan dari instruksi proses maupun hubungan satu proses dengan proses yang lain dengan menggunakan simbol tertentu. Bagan alir digunakan sebagai alat bantu komunikasi dan dokumentasi.

\subsection{Pemodelan Data Entity Relationship Diagram (ERD)}

ERD adalah sebuah model data yang menggunakan beberapa notasi untuk menggambarkan data dalam hal entitas dan relasi yang digambarkan oleh data tersebut.

\subsection{Data Flow Diagram (DFD)}

DFD menggambarkan komponenkomponen sebuah sistem, aliran-aliran data di mana komponen-komponen tersebut, dan asal, tujuan, dan penyimpanan dari data tersebut. Kita dapat menggunakan DFD untuk dua hal utama, yaitu untuk membuat dokumentasi dari sistem informasi yang ada, atau untuk menyusun dokumentasi untuk sistem informasi yang baru.

\section{5 jQuery Mobile}

jQuery Mobile merupakan kerangka kerja JavaScript seperti halnya Jquery pada desktop, Namun penggunaannya khusus ditargetkan untuk perangkat bergerak seperti iPad, iPhone, Blackberry, Symbian, Android, dll. jQuery Mobile memungkinkan pembuatan aplikasi web yang multi platform, atau tidak tergantung pada piranti keras tertentu. jQuery Mobile ini juga telah mendukung penggunaan layar sentuh, sehingga aplikasi kita dapat mengoptimalkan perangkat yang ada.

\subsection{Phonegap}

Phonegap adalah aplikasi yang menampung dan mengizinkan anda untuk membangun secara native aplikasi yang di instal menggunakan HTML, CSS \& JavaScript. Dengan menggunakan Phonegap, pengembang dapat menulis aplikasi mereka sekali dan menyebarkannya ke enam platform mobile utama dan toko aplikasi, termasuk Apple iOS, Android, BlackBerry, WebOS, Samsung bada dan Symbian.

Kode-kode program yang telah dibuat sebelumnya akan di konversi menjadi format yang dapat dibaca oleh sistem operasi mobile. 


\section{PERANCANGAN SISTEM \\ 3.1 Tahap Perancangan Sistem}

Untuk membuat sistem informasi yang baik dibutuhkan perancangan sistem perangkat lunak. Tahapan ini sangat penting karena bertujuan untuk mengidentifikasi berbagai bidang permasalahan yang perlu segera dipecahkan maupun yang nantinya akan diselesaikan. Sesuai dengan metode penelitian tipe Circular perancangan ini terdiri dari analisa sistem berjalan atau analisa sistem lama (sistem yang digunakan sebelum adanya perangkat lunak), analisa kebutuhan, rancangan, implementasi dan pengujian

\subsection{Analisis Kebutuhan}

Analisis kebutuhan bertujuan untuk mengumpulkan kebutuhan - kebutuhan

\subsubsection{Data Produk}

Dalam menjual CD maupun produk lain penjual dalam hal ini admin harus menginformasikan hal - hal yang terkait dengan $\mathrm{CD}$ maupun produk yang dijual lainnya. Data - data yang diolah adalah antara lain :

1. Nama produk : merupakan nama $C D$ maupun produk lain.

2. Harga produk : merupakan harga barang

3. Free goods : merupakan hadiah otentik atau asli dari artis maupun manajemen mereka. Dalam hal ini biasanya poster asli dan photocard artis.

4. Fasilitas lain : fasilitas lain ini misalnya adalah kesanggupan pihak admin untuk mendapatkan $\mathrm{CD}$ bertanda tangan atau ketersediaan free gift lainnya yang bukan official atau hanya buatan fanbase.

\subsubsection{Alur Pembelian pada Sistem Berjalan}

Sebelum adanya perangkat lunak atau aplikasi ini, sistem pembelian import CD sangatlah lama dan rumit.

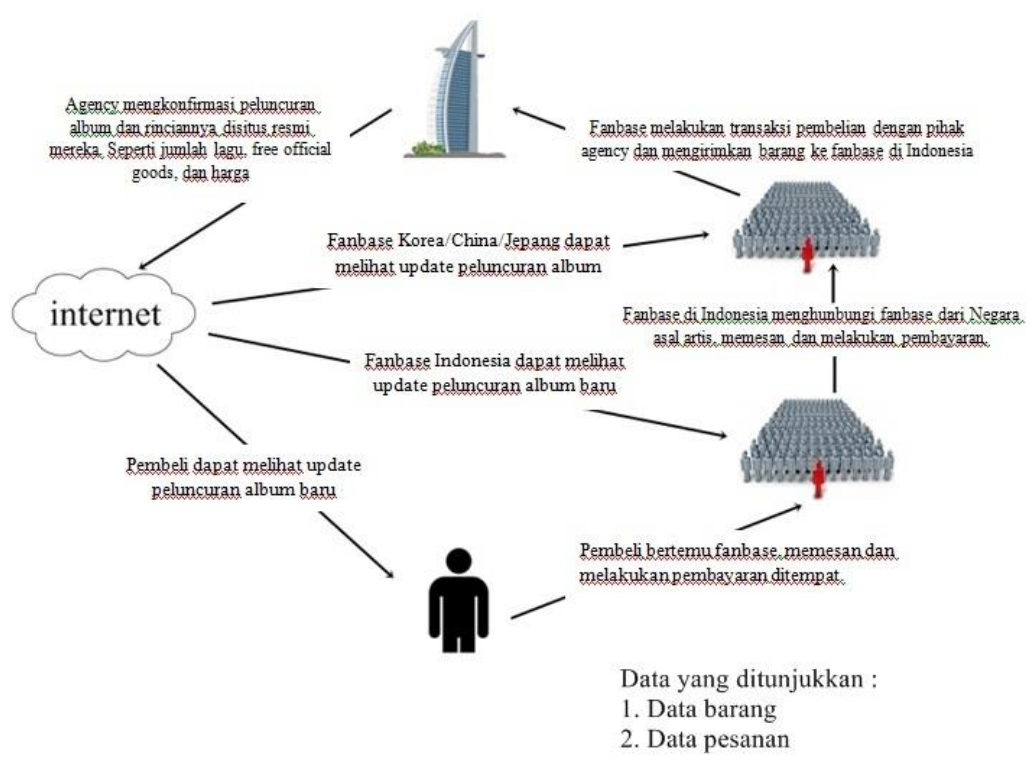

Gambar 1 Alur Sistem Berjalan

Alur sistem yang selama ini telah berjalan sebelum adanya perangkat lunak ini adalah sebagai berikut :

1. Agency yang menaungi artis mengumumkan perilisan album lewat situs resmi mereka.

2. Pembeli melihat update data produk dari agency lewat situs resmi mereka. Namun informas yang lebih aktual dan cepat biasanya berasal dari fanbase.

3. Pembeli memberikan data pesanan dan pembayaran kepada admin fanbase ketika melakukan gathering

4. Admin fanbase Indonesia menghubungi admin fanbase yang berada di negara yang bersangkutan. Misalnya fanbase Girls Generation akan menghubungi fanbase mereka yang bernama SONE di Korea.

5. Admin fanbase dari negara asal artis akan memesan CD maupun produk - produk asli lainnya. Kemudian akan mengirimkan produk tersebut ke Indonesia.

6. Setelah produk tiba di Indonesia, fanbase nasional akan mengirimkan produk pesanan ke fanbase di daerah masing masing atau langsung kepada pembeli. 
Dari Gambar 1 yaitu sistem yang berjalan saat ini ditemukan beberapa kendala sebagai berikut.

Tabel 1Kendala Sistem yang Masih Berjalan

\begin{tabular}{|c|c|c|}
\hline Tahap & Informasi & Kendala \\
\hline $\begin{array}{l}\text { 1. Pemesanan } \\
\text { dari pembeli } \\
\text { ke fanbase } \\
\text { Indonesia. }\end{array}$ & $\begin{array}{l}\text {-Data } \\
\text { pribadi } \\
\text {-Data } \\
\text { Pesanan }\end{array}$ & $\begin{array}{l}\text { - Menunggu } \\
\text { waktu gathering } \\
\text { untuk mendaftar } \\
\text { pesanan. } \\
\text { - Laporan ditulis } \\
\text { secara tradisional. }\end{array}$ \\
\hline $\begin{array}{l}\text { 2. Pemesanan } \\
\text { dari fanbase } \\
\text { Indonesia ke } \\
\text { fanbase } \\
\text { internasional } \\
\text { yang } \\
\text { kemudian } \\
\text { dilanjutkan } \\
\text { ke agency }\end{array}$ & $\begin{array}{l}\text { - Data } \\
\text { pesanan } \\
\text { kumulatif }\end{array}$ & $\begin{array}{l}\text { - Tidak ada } \\
\text { kendala }\end{array}$ \\
\hline $\begin{array}{l}\text { 3.Pendistribusi } \\
\text { an produk }\end{array}$ & $\begin{array}{l}\text { - Data } \\
\text { pesanan } \\
\text { kumulatif }\end{array}$ & $\begin{array}{l}\text { - Pengiriman } \\
\text { produk } \\
\text { merupakan } \\
\text { shipping antar } \\
\text { negara maka } \\
\text { membutuhkan } \\
\text { waktu lama. } \\
\text {-Daftar pemesan } \\
\text { bisa juga hilang } \\
\text { atau rusak karena } \\
\text { masih } \\
\text { menggunakan } \\
\text { cara tradisional } \\
\text { atau dengan } \\
\text { tulisan tangan. }\end{array}$ \\
\hline
\end{tabular}

Setelah mendeskripsikan tahapan kerja dan disertai dengan informasi dan kendala yang ada, admin toko online bersama dengan admin fanbase mencoba mendaftar kebutuhan yang dibutuhkan dalam sistem guna mempermudah proses jual beli. Antara lain adalah sebagai berikut :

1. Manajemen data produk sehingga baik admin maupun pembeli tahu produk apa saja yang tersedia.
2. Manajemen data pemesanan untuk mendinamiskan data pembeli dan jumlah pesanan

3. Manajemen data pembeli sehingga memudahkan admin untuk mengirim produk apabila telah sampai

4. Fasilitas dimana admin dapat mengkonfirmasi proses pembelian seperti misalnya pembayaran masih dalam proses atau sudah lunas

Dan kebutuhan lain yang mendasari penelitian ini adalah teknologi yang memungkinkan pembeli untuk melakukan proses pemesanan dimanapun dan kapanpun tanpa harus bertemu langsung dengan admin fanbase. Yaitu adanya teknologi $m$-commerce untuk XO-Licious

\subsection{Analisis}

Berdasarkan tahapan dari deskripsi umum sebelumnya, muncul beberapa aktor yang terlibat dalam proses jual beli CD yaitu sebagai berikut :

1. Admin merupakan pemilik toko online yang mengelola produk, mengelola laporan pemesanan dan mendistribusikan pesanan. Admin dapat mengetahui data member namun admin tidak dapat mengubah data member.

2. Member merupakan pembeli produk dari toko online. Member adalah pengunjung yang telah melakukan proses pendaftaran. Member dapat mengubah data pribadi yang akan digunakan untuk mengirimkan pesanan oleh admin. Member hanya dapat melihat dan memesan produk namun tidak berhak untuk mengubah data produk.

3. Pengunjung non member merupakan pengunjung e-commerce dan $m$-commerce yang belum melakukan registrasi atau pendaftaran. Pengunjung hanya mampu melihat data produk.

\subsubsection{Kebutuhan Fungsional}

Melihat dari tahapan dan disertai dengan keinginan pengguna dalam fitur yang ada dari aplikasi, dapat disimpulkan beberapa kebutuhan fungsional sebagai berikut : 
1. Login. Merupakan fitur yang berfungsi untuk membagi hak ases pengguna sesuai dengan username dan password yang dimiliki.

2. Umum. Berisi informasi tentang lokasi, cara pembelian dan gallery produk.

3. Transaksi. Berisi fungsi keranjang belanja yang dapat mempermudah mengolah pesanan produk, jumlah harga dan rincian pembelian

4. Administrasi admin. Berupa fungsi yang membantu admin untuk mengolah data pesanan, data produk dan data member

5. Menu tambahan. Berisi fungsi - fungsi tambahan yang diperlukan pengguna. Misalnya fungsi pembatalan pesanan, edit profil hingga menu pembelian via Paypal.

\subsubsection{Kebutuhan Non Fungsional}

Berdasarkan keinginan pengguna untuk membuat sistem berbasis mobile maka spesifikasi kebutuhan non-fungsional yang dibutuhkan adalah sebagai berikut :

1. Operasional. Yaitu dapat diakses pengguna dari berbagai browser yang mendukung javascript dan Dapat diakses di smartphone Android.

2. Antarmuka Interface. Yaitu sistem yang sederhana dan user friendly. pengguna dapat menggunakan aplikasi dengan mudah dan nyaman.

3. Keamanan. Yaitu adanya penggunaan password dalam form login untuk membedakan tipe pengguna termasuk hak akses masing-masing.

\subsection{Perancangan}

Tahap ketiga adalah tahap perancangan perangkat lunak yang merupakan proses multi langkah dan berfokus pada beberapa atribut perangkat lunak. Proses ini berdasarkan dari analisis sebelumnya sehingga menciptakan se-buah rancangan yang sesuai dengan kebutuhan dalam membuat $m$-commerce.

\subsubsection{Pemodelan Data Menggunakan Data Flow Diagram (DFD).}

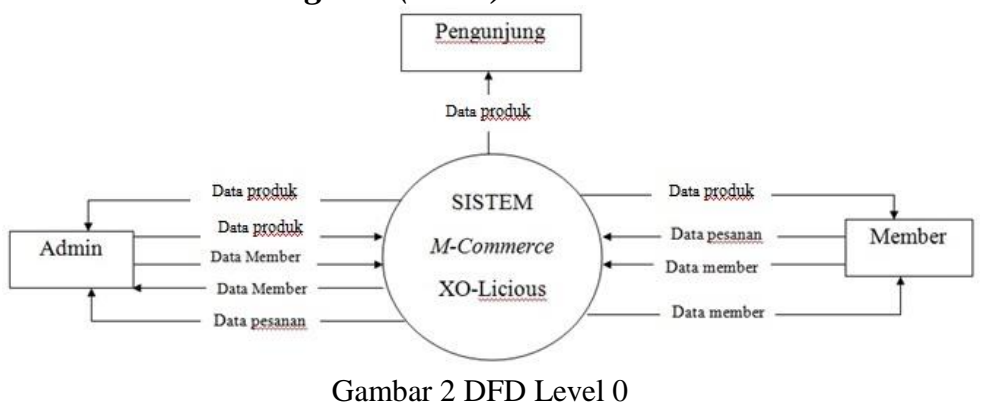

Pada gambar di atas, dalam sistem terdapat 3 pengguna yaitu pengunjung, member dan admin. Pengunjung hanya dapat melihat produk, info lokasi, tentang toko dan cara pembelian. Sedangkan member dan admin memiliki hak - hak yg lebih sesuai dengan kebutuhan masing - masing.

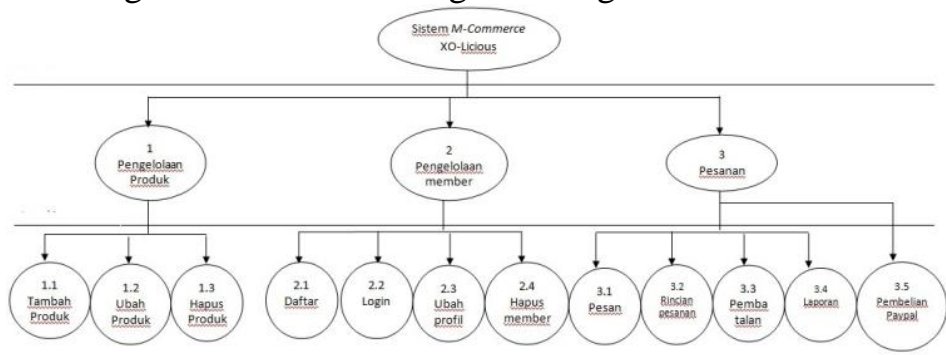

Gambar 3 Dekomposisi Diagram

Dekomposisi diagram adalah bagan hierarki, menunjukkan dekomposisi fungsional top-down dan struktur sistem. Dapat dilihat dari diagram dibawah ini bahwa m-commerce XO-Licious terdiri dari beberapa proses seperti pengelolaan produk, pengelolaan member dan pemesanan.

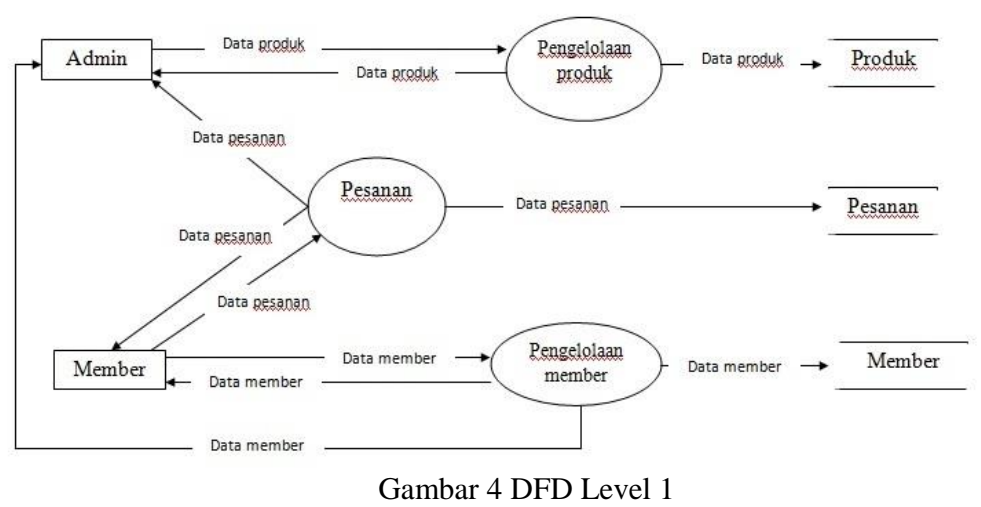


Pada gambar di atas dijelaskan bahwa admin memiliki hak untuk mengelola produk. Member memiliki hak untuk menggunakan fungsi pengelolaan data member seperti registrasi, login, dan juga mengubah profil. Member dapat melakukan pesanan dan berhak mendapatkan rincian pesanan. Admin berhak menerima konfirmasi pesanan dari fungsi pesanan. Admin memiliki hak untuk melihat member namun tidak memiliki hak untuk mengubah data member. Untuk mengetahui proses pengiriman dan penerimaan data pada sistem, di bawah ini merupakan penjabaran dari fungsi - fungsi di atas.

\subsubsection{Perancangan Basis Data Menggunakan Entity Relationship Diagram (ERD) \\ Dalam membuat ERD ada beberapa} tahapan antara lain :

\section{Menentukan entitas}

Dimulai dengan mengidentifikasi dan menetapkan seluruh himpunan entitas yang terlibat.

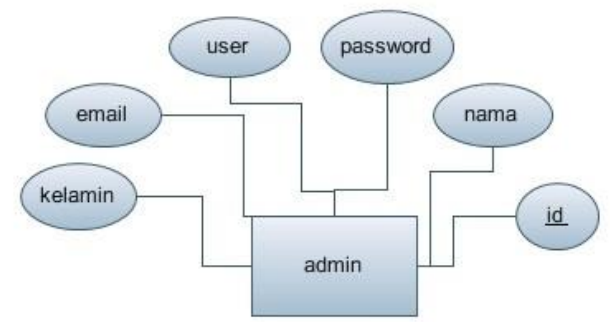

Gambar 5 Atribut Entitas Admin

- Atribut key: id

- Atribut tunggal : nama, password, user, email dan kelamin

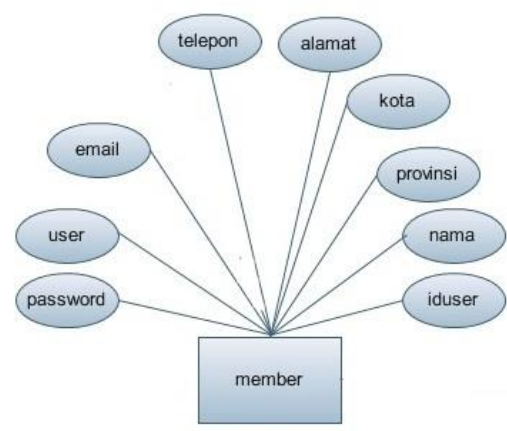

Gambar 6 Atribut Entitas Member
- Atribut key: iduser

- Atribut tunggal : nama, profinsi, kota, alamat, telepon, email, user, password

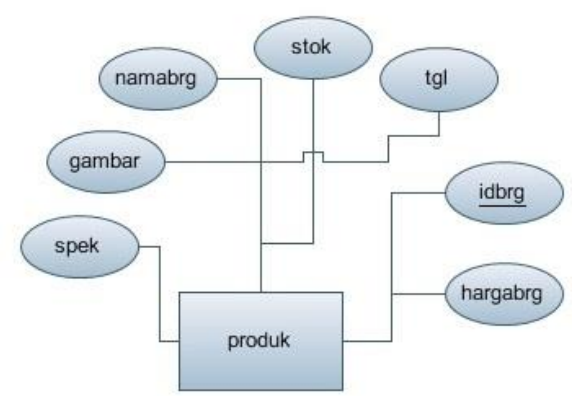

Gambar 7 Atribut Entitas Produk

- Atribut key: $\underline{\mathrm{idbrg}}$

- Atribut tunggal : namabrg, stok, tgl, gambar, spek, hargabrg

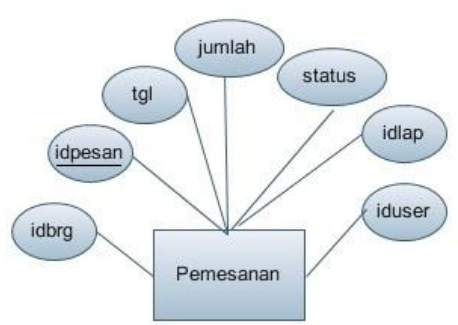

Gambar 8 Atribut Entitas Pemesanan

- Atribut key: idpesan

- Atribut tunggal : iduser, idbrg, tgl, jumlah, status, idlap

2. Menentukan Relasi Antar Entitas

Pada relasi gambar di bawah ini, entitas member dan produk membentuk suatu relasi dan menghasilkan suatu atribut relasi pemesanan. Relasi antara entitas member dan produk sendiri merupakan entitas $\mathrm{M}$ : $\mathrm{M}$ (many to many). Dalam relasi pemesanan atribut yang bertindak sebagai penghubung yaitu iduser dan idbrg

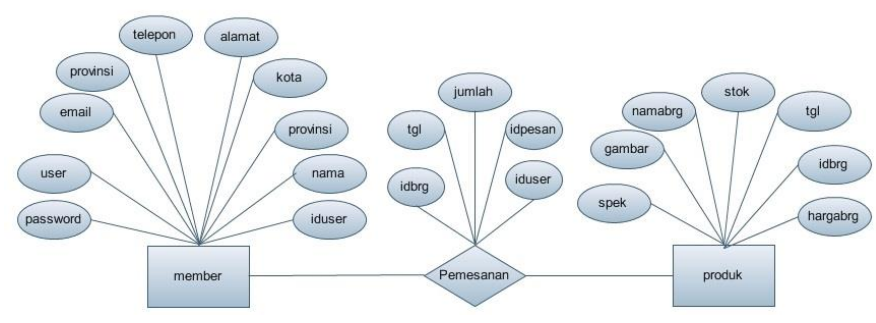

Gambar 9 Atribut Entitas Member 
3. Transformasi ke tabel

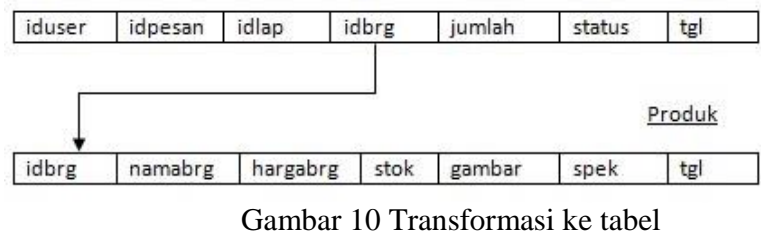

Dilakukan setelah menentukan entitas, atribut beserta dengan relasinya. Kemudian mentrasformasikan ke dalam tabel. Berdasarkan gambar di atas, terlihat tabel pemesanan yang merupakan entitas lemah memiliki idbrg yang terhubung dengan idbrg dari tabel cabang.

\subsubsection{Diagram Alir Fungsi Aplikasi}

Berikut merupakan diagram alir dari jalannya fungsi-fungsi dalam sistem $m$ commerce adalah :

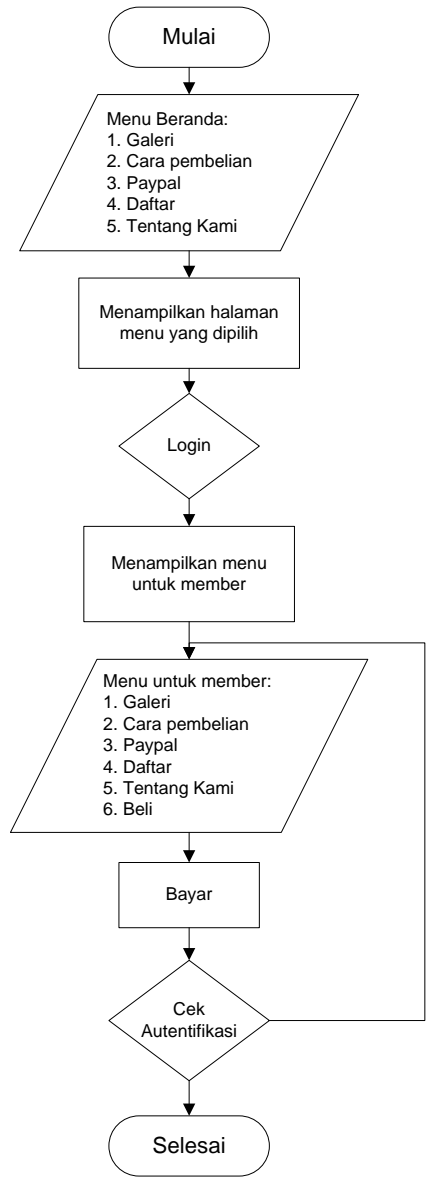

Gambar 11 Diagram Alir Sistem M-commerce

\section{IV.PENGUJIAN \\ DAN \\ USER \\ INTERFACE \\ 4.1 Pengujian}

Tabel 2 Tabel Pengujian

\begin{tabular}{|c|c|c|c|}
\hline $\begin{array}{c}\text { Nama } \\
\text { Pengujian }\end{array}$ & $\begin{array}{c}\text { Bentuk } \\
\text { Pengujian }\end{array}$ & $\begin{array}{l}\text { Hasil Yang } \\
\text { Diharapkan }\end{array}$ & $\begin{array}{c}\text { Hasil } \\
\text { Pengujian }\end{array}$ \\
\hline $\begin{array}{l}\text { Pengujian } \\
\text { Login }\end{array}$ & $\begin{array}{c}\text { Memasukk } \\
\text { an } \\
\text { username } \\
\text { dan } \\
\text { password }\end{array}$ & $\begin{array}{c}\text { Muncul } \\
\text { tampilan } \\
\text { halaman } \\
\text { utama }\end{array}$ & Berhasil \\
\hline $\begin{array}{l}\text { Pengujian } \\
\text { Menu } \\
\text { pemesanan } \\
\text { barang }\end{array}$ & $\begin{array}{l}\text { 1. Memilih } \\
\text { barang } \\
\text { yang akan } \\
\text { dibeli. } \\
\text { 2. Mencetak } \\
\text { hasil } \\
\text { pemesana } \\
\text { n barang, } \\
\text { mengecek } \\
\text { adanya } \\
\text { kode } \\
\text { pembelian }\end{array}$ & $\begin{array}{c}\text { Muncul } \\
\text { barang yang } \\
\text { akan } \\
\text { dipesan, } \\
\text { member } \\
\text { dapat } \\
\text { mencetak } \\
\text { rincian } \\
\text { pemesanan, } \\
\text { muncul kode } \\
\text { pemesanan }\end{array}$ & Berhasil \\
\hline $\begin{array}{l}\text { Pengujian } \\
\text { Menu } \\
\text { Manajemen } \\
\text { Produk }\end{array}$ & $\begin{array}{l}\text { 1. Menambah } \\
\text { barang } \\
\text { 2. Edit } \\
\text { barang } \\
\text { 3. Hapus } \\
\text { barang }\end{array}$ & $\begin{array}{l}\text { Admin dapat } \\
\text { menambah, } \\
\text { mengubah } \\
\text { dan } \\
\text { menghapus } \\
\text { barang }\end{array}$ & Berhasil \\
\hline $\begin{array}{l}\text { Pengujian } \\
\text { Menu } \\
\text { Pendaftaran } \\
\text { Member }\end{array}$ & 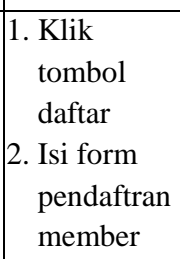 & $\begin{array}{c}\text { Pengunjung } \\
\text { dapat } \\
\text { mendaftar } \\
\text { menjadi } \\
\text { member }\end{array}$ & Berhasil \\
\hline $\begin{array}{l}\text { Pengujian } \\
\text { Menu } \\
\text { Manajemen } \\
\text { Member }\end{array}$ & $\begin{array}{l}\text { 1. Lihat } \\
\text { member } \\
\text { 2. Hapus } \\
\text { member }\end{array}$ & $\begin{array}{c}\text { Admin dapat } \\
\text { menghapus } \\
\text { member } \\
\text { yang telah } \\
\text { mendaftar }\end{array}$ & Berhasil \\
\hline $\begin{array}{l}\text { Pengujian } \\
\text { Penggantian } \\
\text { Satus } \\
\text { Pemesanan }\end{array}$ & \begin{tabular}{|l} 
1. Pilih \\
pesanan \\
yang ingin \\
diubah \\
statusnya. \\
2. Pilih
\end{tabular} & $\begin{array}{c}\text { Status } \\
\text { pesanan } \\
\text { member } \\
\text { menjadi } \\
\text { lunas dan } \\
\text { member } \\
\text { dapat }\end{array}$ & Berhasil \\
\hline
\end{tabular}




\begin{tabular}{|c|c|c|c|}
\hline $\begin{array}{c}\text { Nama } \\
\text { Pengujian }\end{array}$ & $\begin{array}{c}\text { Bentuk } \\
\text { Pengujian }\end{array}$ & $\begin{array}{l}\text { Hasil Yang } \\
\text { Diharapkan }\end{array}$ & $\begin{array}{c}\text { Hasil } \\
\text { Pengujian }\end{array}$ \\
\hline & $\begin{array}{l}\text { status } \\
\text { menjadi } \\
\text { lunas, } \\
\text { kemudian } \\
\text { klik } \\
\text { tombol } \\
\text { proses }\end{array}$ & $\begin{array}{c}\text { membeli } \\
\text { barang lagi }\end{array}$ & \\
\hline $\begin{array}{c}\text { Pengujian } \\
\text { Logout }\end{array}$ & $\begin{array}{l}\text { Mengklik } \\
\text { menu } \\
\text { Logout }\end{array}$ & $\begin{array}{c}\text { Kembali ke } \\
\text { halaman } \\
\text { utama } \\
\text { pengunjung }\end{array}$ & Berhasil \\
\hline $\begin{array}{l}\text { Pengujian } \\
\text { Pembelian } \\
\text { via Paypal }\end{array}$ & $\begin{array}{l}\text { 1. Pilih menu } \\
\text { pembelian } \\
\text { via paypal. } \\
\text { 2. Pilih } \\
\text { produk }\end{array}$ & $\begin{array}{c}\text { m-commerce } \\
\text { terhubung ke } \\
\text { paypal } \\
\text { admin }\end{array}$ & Berhasil \\
\hline
\end{tabular}

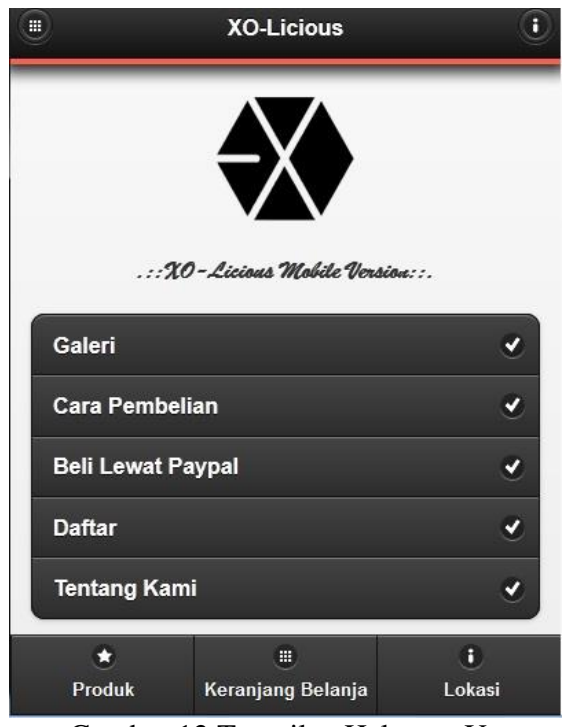

Gambar 12 Tampilan Halaman Utama

Di atas ini merupakan tampilan awal atau beranda dari aplikasi m-commerce XO-Licious.

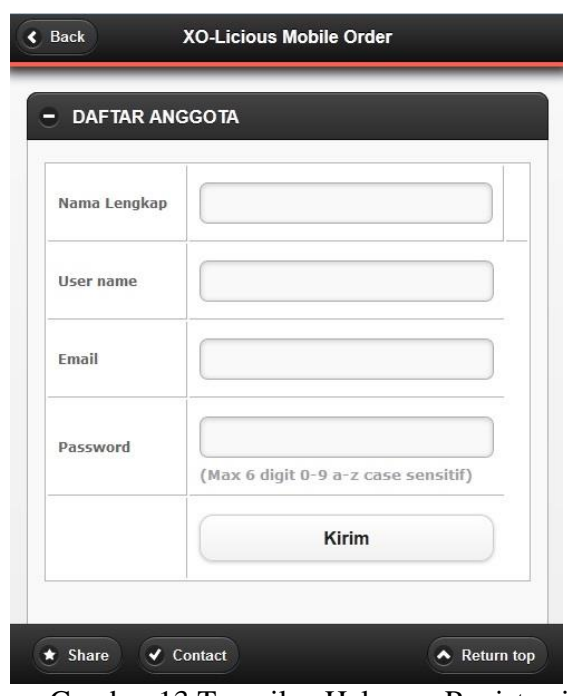

Gambar 13 Tampilan Halaman Registrasi

Untuk melakukan registrasi maka pembeli harus memilih menu registrasi dan kemudian mengisi kolom - kolom seperti pada form di atas.

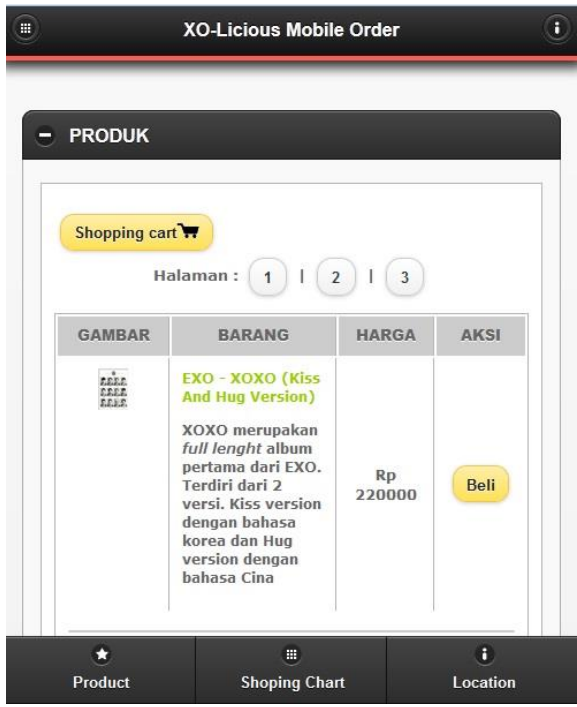

Gambar 14 Tampilan Halaman Produk

Gambar di atas menunjukkan tampilan daftar produk yang disediakan oleh toko. 


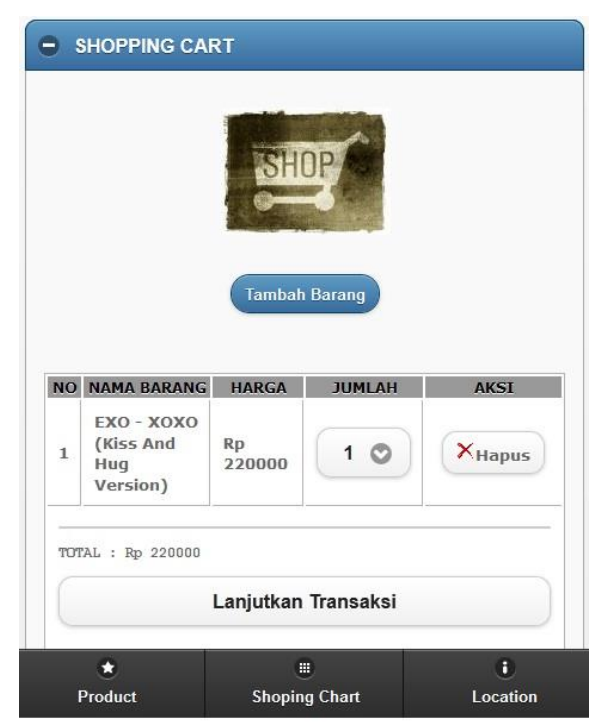

Gambar 15 Tampilan Halaman Keranjang Belanja

Gambar di atas menunjukkan menu keranjang belanja. Di dalam halaman ini terdapat beberapa menu lainnya yang dapat digunakan oleh pengguna contohnya tombol tambah barang untuk menambahkan produk lain yang ingin dibeli.

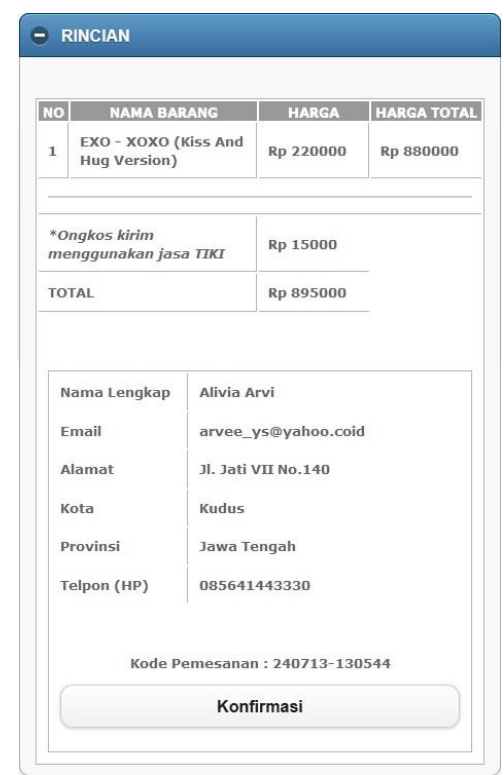

Gambar 16 Tampilan Halaman Rincian Belanja

Gambar di atas merupakan rincian transaksi berupa jumlah total belanja dan ongkos kirim. Serta rincian alamat pengiriman serta nama pelanggan

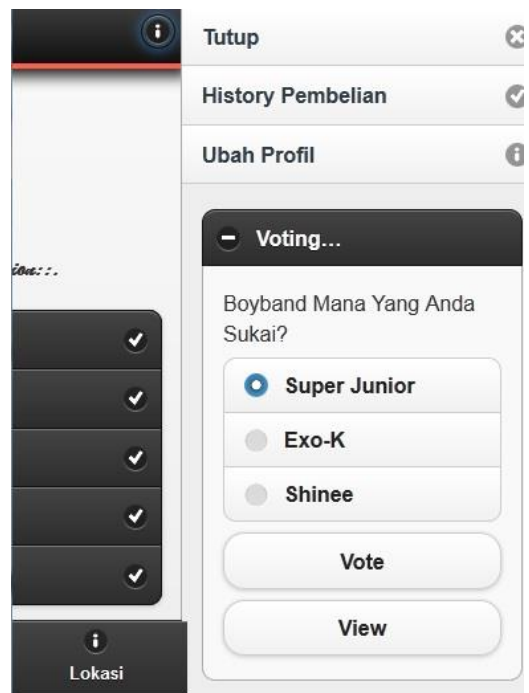

Gambar 17 Tampilan Halaman Menu Tambahan

Gambar di atas merupakan tampilan menu tambahan seperti history penjualan serta edit profil.

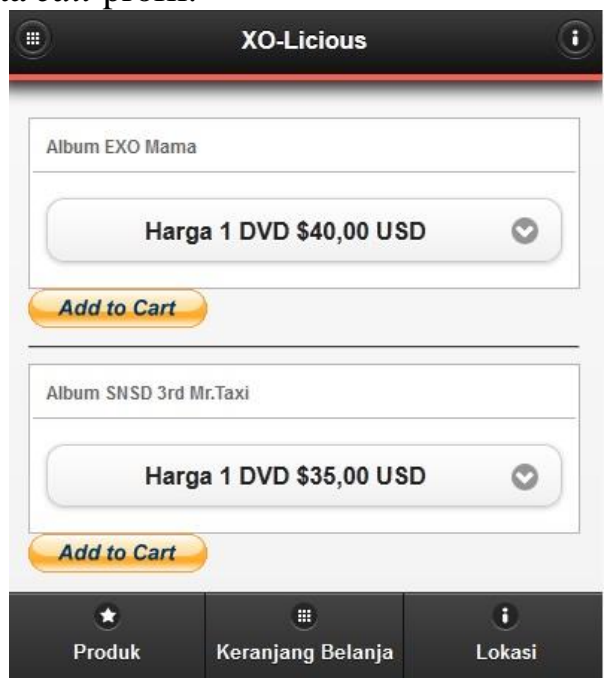

Gambar 18 Tampilan Halaman Pembelian via Paypal

Gambar di atas merupakan tampilan menu transaksi melalui Paypal.

Sebelum melakukan manajemen produk, manajemen member dan manajemen pemesanana, admin harus melakukan proses login ke halaman admin terlebih dahulu. 


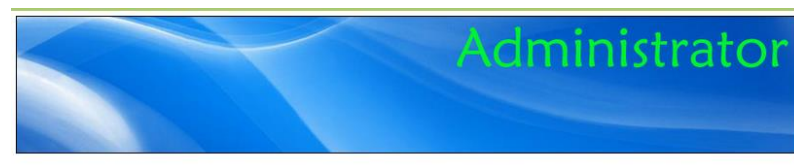

Home Pemesanan Edit Produk Edit Profil Edit Menber Edit Forum Edit Guestbook Logout
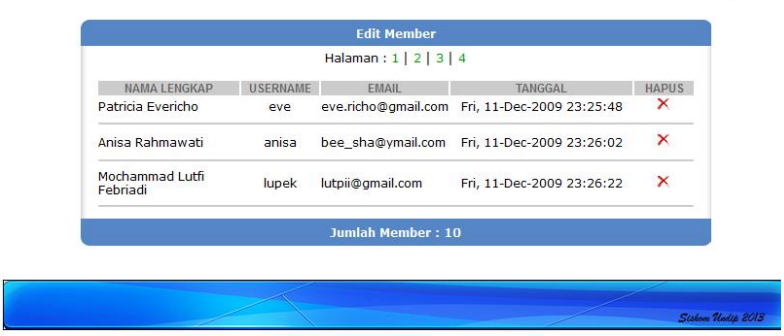

Gambar 19 Tampilan Halaman Manjemen Admin

Gambar di bawah ini merupakan tampilan manajemen pemesanan. Dimana admin dapat merubah status pemesanan dari proses menjadi lunas.

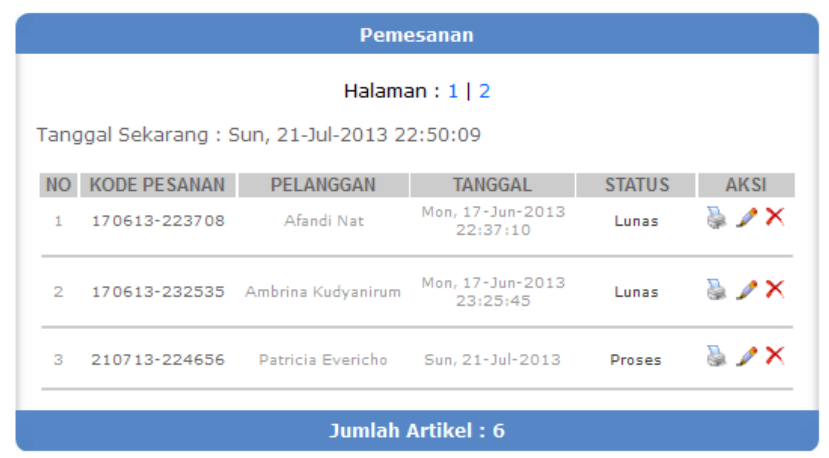

Gambar 20 Tampilan Halaman Manajemen Pemesanan

Gambar di bawah ini merupakan tampilan manajemen produk dimana admin dapat menambah, menghapus maupun mengganti isi dari konten produk.

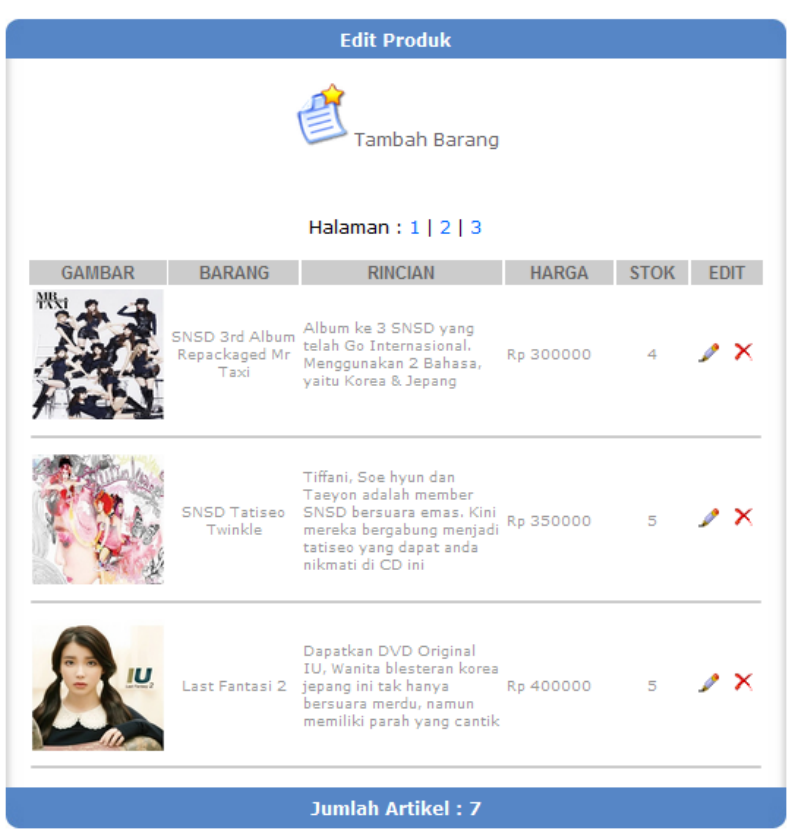

Gambar 21 Tampilan Halaman Manajemen Produk

\section{KESIMPULAN DAN SARAN \\ 5.1. Kesimpulan}

1. Hasil penelitian yang ditunjukkan selama proses pengujian sesuai dengan rancangan sistem aplikasi. Maka dapat disimpulkan bahwa aplikasi toko online berbasis mobile web ini telah berhasil dikembangkan dan dapat berfungsi dengan baik.

2. Aplikasi toko online berbasis mobile web ini dapat menjadi alternatif untuk dapat melakukan proses jual beli kapanpun dan dimanapun. Dan aplikasi berbasis mobile web ini dapat diakses melalui web browser pada smartpone dengan alamat http://www.fisikadion.web.id/

3. Karena aplikasi ini terhubung dengan internet, aplikasi ini dapat berjalan dengan lancar apabila koneksi internet pada perangkat juga lancar.

\subsection{Saran}

1. Perlu dilakukan penelitian lebih lanjut untuk penambahan pembayaran online melalui paypal yang terintegrasi pada aplikasi $m$-commerce. 
2. Perlu dilakukan penelitian lebih lanjut mengenai bagaimana membuat agar $m$ commerce dapat diterapkan lintas sistem operasi seperti Blackberry, iOS dan Windows Phone.

\section{DAFTAR PUSTAKA}

Al Fatta, Hanif, 2007, Analisis dan Perancangan Sistem Informasi untuk Keunggulan Bersaing Perusahaan dan Organisasi Modern, Penerbit ANDI, Yogyakarta.

Kadir, Abdul, 2009, Dasar Perancangan dan Implementas, Penerbit ANDI, Yogyakarta.

Kalkota, Ravi dan Whinston Andrew, 1996, Electronic Commerce : A Manager's Guide.

Katz, David, 1996, Design For Response: Creative Direct Marketing That Works.

Madcoms, 2004, Aplikasi Program PHP dan $M y S Q L$, Penerbit ANDI, Yogyakarta.

Sarwono, Jonathan dan Taryana, 2007, Membuat Web Site Bisnis dan Pribadi dengan HTML, Gava Media, Yogyakarta.

Sutabri, Tata, 2004, Analisis Sistem Informasi, Penerbit ANDI, Yogyakarta.

Suyanto, 2003, Strategi Periklanan Pada ECommerce Perusahaan Top Dunia, Penerbit ANDI, Yogyakarta.

Tim EMS, 2013, Pemrograman Mobile dengan PhoneGap, Elex Media Komputindo, Jakarta.

Whitten, Jeffrey L. dkk, 2004, Metode Desain dan Analisis Sistem, Penerbit ANDI, Yogyakarta.

Yakub, 2012, Pengantar Sistem Informasi, Graha Ilmu, Yogyakarta.

Zaki, Ali dan W. Edy, 2012, Membuat Web Mobile dengan jQuery Mobile, Elex Media Komputindo, Jakarta.

\section{BIODATA PENULIS}

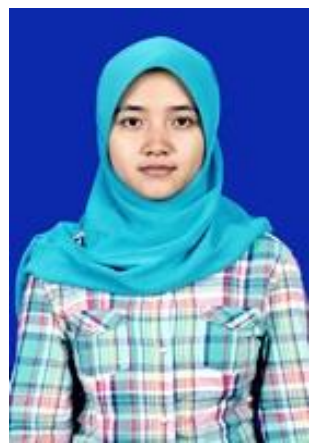

Alifvia Arvi ningrum, lahir di Kudus, 30 April $1990 . \quad$ Menempuh pendidikan mulai dari TK Pertiwi Jati Kulon. Kemudian melanjutkan ke SDN Jati Kulon 1 Kudus, SMP 1 Kudus, SMA 1 Kudus dan saat ini sedang melanjutkan pendidikan Strata Satu di Jurusan Sistem Komputer Fakultas Teknik Universitas Diponegoro Semarang angkatan 2008.

$$
\begin{gathered}
\text { Mengetahui/Mengesahkan } \\
\text { Dosen Pembimbing I }
\end{gathered}
$$

\section{Ir. Kodrat Iman Satoto, M.T. NIP 196310281993031002}

\author{
Mengetahui/Mengesahkan \\ Dosen Pembimbing II
}

\section{Rinta Kridalukmana, S.Kom., M.T. NIP 197706152008011011}

